\title{
Ischaemic colitis caused by polyethylene glycol with ascorbic acid bowel preparation agent
}

\author{
Soo In Choi, Jeongmin Choi
}

Department of Internal Medicine, Inje University Sanggye Paik Hospital, Seoul, The Republic of Korea

\section{Correspondence to Dr Jeongmin Choi;} doct00@hanmail.net

Accepted 23 October 2021

Check for updates

(C) BMJ Publishing Group Limited 2021. No commercial re-use. See rights and permissions. Published by BMJ.

To cite: Choi SI, Choi J. BMJ Case Rep 2021;14:e245891. doi:10.1136/bcr-2021245891

\section{DESCRIPTION}

Various bowel preparation agents have been developed for effective and safe bowel cleansing before colonoscopy. Polyethylene glycol (PEG) is widely used in the elderly. A 2L PEG solution with ascorbic acid (PEG-Asc) was developed to reduce the volume of standard 4L PEG.

Several cases of ischaemic colitis caused by stimulant laxatives or hyperosmolar bowel preparation agents have been reported. ${ }^{1-5}$ However, PEG-Asc-induced ischaemic colitis has rarely been reported. Here, we report a rare case of ischaemic colitis after administration of PEG-Asc.

A 78-year-old woman with hypertension and diabetes was admitted for colonoscopic polypectomy. Two hours after the administration of 1L of PEG-Asc (PEG 3350 200g, ascorbic acid plus sodium ascorbate 21g, Coolprep, Taejoon Pharm., Korea), she complained of cramping pain in the lower abdomen and maroon-coloured haematochezia mixed with lavage fluid. Her vital signs were stable and her abdomen was soft and palpated with moderate tenderness. Laboratory data showed a haemoglobin level of $128 \mathrm{~g} / \mathrm{L}$, white blood cell count of $15.4 \times 10^{9} / \mathrm{L}$, and C reactive protein level of $3.61 \mathrm{mg} / \mathrm{dL}$. Other laboratory data were normal. Abdominal CT revealed severe wall thickening in the sigmoid colon (figure 1A). The next morning, the colonoscopy identified severe mucosal oedema and diffuse haematomas in the sigmoid colon, indicating ischaemic colitis (figure 1B). The rectal mucosa was normal (figure 1C). Colonoscopy did not reach the descending colon due to oedema of the colon wall. Pathologic examination confirmed ischaemic colitis.

As the patient had no signs of bowel necrosis or perforation, she was managed conservatively using intravenous fluids, fasting and empirical antibiotics. She gradually recovered and was discharged on the seventh hospital day without complications.

Two months after discharge, a follow-up colonoscopy was planned for colon polypectomy. The patient and her family were concerned about recurrent ischaemic colitis after bowel preparation. At this time, a small amount of PEG-Asc $(500 \mathrm{~mL})$ was administered to the patient. Diet restrictions that allow only a liquid diet and oral hydration were recommended. Intravenous fluid was administered to prevent fluid loss. Colonoscopy revealed a completely normal colonic mucosa in the sigmoid colon (figure 1D). The bowel preparation was good and the patient successfully underwent colon polypectomy for $2 \mathrm{~cm}$-sized polyps in the ascending colon.

To date, only two cases of ischaemic colitis induced by PEG-based bowel laxatives have been reported. ${ }^{67}$

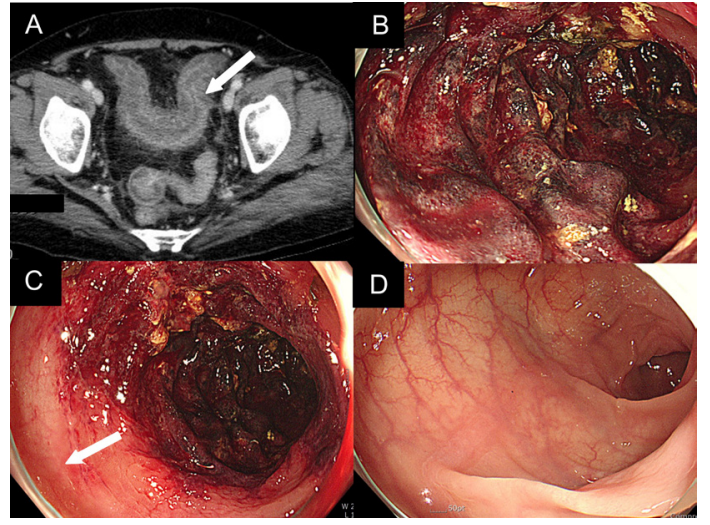

Figure 1 Ischaemic colitis caused by PEG-Asc bowel preparation agent. (A) Abdominal CT revealed severe wall thickening in the sigmoid colon (arrow). (B) Colonoscopy identified severe mucosal oedema and diffuse haematomas in the sigmoid colon. (C) Colonoscopy showed normal rectal mucosa (arrow). Colonoscopy identified the involved sigmoid colon and the uninvolved rectum, which is a typical endoscopic feature of ischaemic colitis. (D) A follow-up colonoscopy after 2 months revealed a completely normal colonic mucosa in the sigmoid colon. PEG-Asc, PEG solution with ascorbic acid.

A 70-year-old man with chronic constipation experienced ischaemic colitis after receiving $4 \mathrm{~L}$ of PEG solution before colonoscopy. ${ }^{6}$ An 82 -year-old woman with faecal obstruction experienced nearly lethal mesenteric ischaemia after taking 1L of PEG-Asc. ${ }^{7}$ We consider that the latter case is acute mesenteric ischaemia secondary to faecal mechanical obstruction exacerbated by colonic laxatives, rather than the diagnosis of ischaemic colitis.

The mechanism of PEG-induced ischaemic colitis is unclear or idiosyncratic. One explanation is that PEG

\section{Learning points}

Although PEG solution with ascorbic acid (PEG-Asc) bowel preparations are widely used and known to be relatively safe, in rare cases, patients may develop ischaemic colitis.

- Clinicians should be aware of the possibility of ischaemic colitis in at-risk patients and take a preventive approach during the next colonoscopy.

- Intravenous fluids hydration and reducing the dose of the preparation may help prevent recurrent ischaemic colitis. 
can cause dehydration due to fluid loss, leading to hypoperfusion of the colonic vasculature. In the case of non-obstructive mesenteric ischaemia induced by PEG-Asc, ${ }^{7}$ dehydration may aggravate this complication. It is necessary to instruct the patient to adequately hydrate during bowel preparation.

Twitter Soo In Choi @sooin

Contributors $\mathrm{SIC}$ and JC contributed equally to this manuscript regarding data acquisition, analysis, interpretation, drafting and critical revision.

Funding The authors have not declared a specific grant for this research from any funding agency in the public, commercial or not-for-profit sectors.

Competing interests None declared.

Patient consent for publication Consent obtained directly from patient(s).

Provenance and peer review Not commissioned; externally peer reviewed.

Case reports provide a valuable learning resource for the scientific community and can indicate areas of interest for future research. They should not be used in isolation to guide treatment choices or public health policy.
ORCID ID

Jeongmin Choi http://orcid.org/0000-0001-6976-9887

\section{REFERENCES}

1 Lee CK, Lee S-H, Lee JY. A case of ischemic colitis following oral osmotic laxative for bowel preparation. Intest Res 2008;6:135-9.

2 Oh JK, Meiselman M, Lataif LE. Ischemic colitis caused by oral hyperosmotic saline laxatives. Gastrointest Endosc 1997;45:319-22.

3 Baudet J-S, Castro V, Redondo I. Recurrent ischemic colitis induced by colonoscopy bowel lavage. Am J Gastroenterol 2010;105:700-1.

4 Sugiyama M, Kusumoto E, Ota M, et al. Induction of potentially lethal hypermagnesemia, ischemic colitis, and toxic megacolon by a preoperative mechanical bowel preparation: report of a case. Surg Case Rep 2016;2:18.

5 Chung JW, Lee JM, Sohn YW, et al. Ischemic colitis associated with low-volume oral sulfate solution for bowel preparation. Korean I Gastroenterol 2020;75:216-9.

6 You JH, Choi ST, Kim DH. A case of ischemic colitis by oral sulfate free-polyethylene glycol. Intest Res 2009;7:129-32.

7 Ishii R, Sakai E, Nakajima K, et al. Non-occlusive mesenteric ischemia induced by a polyethylene glycol with ascorbate-based colonic bowel preparation. Clin J Gastroenterol 2019;12:403-6.

Copyright 2021 BMJ Publishing Group. All rights reserved. For permission to reuse any of this content visit

https://www.bmj.com/company/products-services/rights-and-licensing/permissions/

BMJ Case Report Fellows may re-use this article for personal use and teaching without any further permission.

Become a Fellow of BMJ Case Reports today and you can:

- Submit as many cases as you like

- Enjoy fast sympathetic peer review and rapid publication of accepted articles

- Access all the published articles

- Re-use any of the published material for personal use and teaching without further permission

Customer Service

If you have any further queries about your subscription, please contact our customer services team on +44 (0) 2071111105 or via email at support@bmj.com.

Visit casereports.bmj.com for more articles like this and to become a Fellow 